\title{
OVERVIEW OF THE MOST EXCEPTIONAL FIELDS OF MUNICIPAL POLICES IN THE SLOVAK REPUBLIC
}

\author{
Nina Molovcakova \\ University of Zilina, Faculty of Security Engineering, Department of Security \\ Management, Zilina, Slovakia \\ CMESTE \\ JEL Category: K15
}

\begin{abstract}
The article describes statistical comparisons that give a realistic picture of development trends in the field of general police activities. Based on the comparison of data of the years 2009 to 2018 in the offenses section, it is possible to note overall decreasing tendencies, apart from offenses against road and traffic safety. The article describes the direction of development of the general police and their basic functions, among which we find the protection of the public order in villages. It can be said that the activity and focus of the general police depend on the security situation of the given region, as well as on the priorities of the designated municipal authorities with the established municipal police. The Municipal Police is an order unit operating in the provision of public order in the city, protecting the environment in the city, and performing the tasks resulting from the generally binding regulations of the city, the resolutions of the municipal council, and the decision of the mayor. The activity of the municipal police is governed by its chief. The city police chief is appointed and dismissed by the city council on the proposal of the mayor. The city may also define other tasks for the municipal police if specific laws so provide. The city council determines the organization, the wages and the scope of technical means of the municipal police, taking into account the scope of their tasks. The Municipal policers are employees of the Municipal Police which is the employee of the city. They have the status of public officials when performing tasks. The status, roles, organizational structure, mutual relations, relations with state administration bodies and other organizations are regulated by a special law, organizational regulations of the city, the working orders of the city and the municipal police, and generally binding regulation of the city.
\end{abstract}

Keywords: general police, offenses, cooperation, the security situation, Municipal Police

\section{INTRODUCTION}

Ensuring security is one of the decisive assumptions which has an immediate impact on

Address of the corresponding author:

Nina Molovčáková

䒠”nina.kralikova@gmail.com the development of our company. However, the risk to life, health, and property is not completely excluded. One of the basic tasks of the municipal police is to ensure prevention, primarily through discussions and lectures in schools, e.g. about the work of the municipal police, where children and young people get acquainted with the equipment and armaments of the members of the municipal 
police, but they also deal with issues such as security and crime prevention in the municipality and also possible cooperation with members of the municipal police. As part of this activity, general police carry out lectures at primary, secondary and nursery schools. In addition to lecturing, members of the municipal police organize, eventually, they help organize various activities for children, such as organizing sports events, children's camps for socially dependent children. The legislature has empowered the general police to clarify the offenses that they are entitled to negotiate in the block procedure. This is a relatively wide area of this unlawful conduct, covering the offenses listed in the Act of the Slovak National Council no. 372/1990 Coll. on offenses, as amended (hereinafter referred to as "the Act on Offenses"), in the Act on Municipal Police and other regulations. Municipal police cooperate with local police corps. (Report on the Activities, 2018). Most of the municipal police perceive and evaluate the cooperation with the police departments highly positively. The most common areas of cooperation with the Police Force are the following: provision of public order, checks in hospitality facilities in the evening and night hours in connection with the protection of minors and juveniles before serving alcoholic beverages and other addictive substances; security actions, reporting rumors, searching for wanted persons, things and motor vehicles, providing records from city camera systems to verify suspected offense or offense.

\section{CHARACTERISTIC OF MUNICIPAL POLICE}

Municipal police were established after 1989 as an alternative to the Police Force for the purpose of ensuring public order, environmental protection in municipalities and in order to fulfill tasks related to environmental protection in municipalities and cities, in fulfilling tasks resulting from generally binding regulations of municipalities and cities, from resolutions of municipal and municipal councils and decisions of mayors of municipalities or mayors of towns. Municipal police are part of the critical infrastructure of municipalities. They can be included in the security field. The municipal police are established and abolished by a generally binding regulation. The municipal police perform the tasks of municipal police in municipalities that are cities. (Crime prevention strategy, 2018)

\subsection{Basic tasks of the municipal police}

Municipal Police:

- secures public order in the municipality, cooperates in the protection of its inhabitants and other persons in the municipality against the threat to their life and health,

- cooperate with the relevant units of the Police Force in the protection of municipal property, the property of citizens, as well as other property in the municipality against damage, destruction, loss or misuse, including the use of centralized signaling systems and other security systems (central protection desks),

- Ensures environmental protection in the municipality

- Ensures order, cleanliness, and hygiene in the streets, other public spaces and public places

- it implements generally binding regulations of the municipality, resolutions of the municipal council and decisions of the mayor,

- imposes and levies in block proceedings fines for offenses established by a special regulation and also for offenses against safety and fluency of road traffic committed by failure to comply with the prohibition resulting from the modification of road traffic made by road signs or transport facilities;

- Notifies the competent authorities of any breach of the law it detects in the performance of its tasks and which is not the responsibility of the municipality.

- performs tasks in the field of prevention within the scope of the law.

The municipality may also define the municipal police with other tasks if it is provided by specific laws. (Law,2019)

\subsection{Organization of municipal police}

The organization, the number of wage resources and the scope of technical means of the municipal police are determined by the municipal council taking into account the scope of its tasks. The general police are members of the municipal police who are employees of the municipality. They have the status of a public official when performing tasks. Members of the municipal police 
can only be a blameless person older than 21 years, who is physically, mentally and professionally competent to perform the tasks of the municipal police.

\section{Management and representation}

The activity of the municipal police is controlled by its chief. To this end, in particular:

a. organize the work of members of the municipal police,

b. report to the Mayor of the Municipality on the general public order situation and the results of the activities of the municipal police; he will notify him of major events immediately,

c. cooperate with the Head of the relevant Police Corps department, State authorities, authorities, environmental authorities and other bodies,

d. submit to the Mayor the requirements for ensuring the operation of the Municipal Police is responsible for the efficient use of the funds entrusted,

e. provide training and training for members of the municipal police,

f. submits proposals to the Mayor relating to the employment relationships of members municipal police,

g. perform other tasks according to the organizational order and instructions of the mayor.

At the time of his absence, the chief is represented by a local police officer. In municipalities, where appropriate, the municipal council may, on the proposal of the mayor, establish the function of permanent deputy chief. (Law,2019)

\subsection{Obligations and authorizations of Municipal police officers}

A member of the municipal police is obliged to perform tasks in particular:

a. comply with laws and other generally binding legislation instructions of the chief or instructions of the mayor,

b. to respect the dignity, honor, and dignity of the citizens and their own and not to allow it unjustified harm has arisen to citizens in connection with the activities of the municipal police and any interference with their rights and freedoms did not exceed the level necessary to achieve purpose pursued by the intervention, c. to intervene according to their abilities and abilities within the limits of this Act and others generally binding legislation, or make other necessary measures where there is reasonable suspicion that a criminal offense has been committed or offense, other administrative offense or otherwise disturbed public order,

d. to intervene if a life, health or property damage is at risk; it may not do so if it would pose a serious threat to themselves or others,

e. notify the Police Corps of a case where a criminal offense has been committed to the prosecutor and, depending on the nature of the case, also prevent unauthorized persons from entering the venue,

f. instructing a person to exercise their rights,

g. report deficiencies that threaten or are impeded without delay to the Chieftain making their activities more difficult.

The municipal police officer is entitled to perform tasks:

a. invite the person to refrain from conduct which infringes public policy or from other unlawful conduct,

b. impose and collect fines for offenses found in the performance of tasks in the block proceeding,

c. to detain a person caught in or immediately after the commission of the offense and immediately hand it over to the nearest police force; if it's a person you're looking for to show it to the municipal police department for explanation and to do things according to special regulations,

d. ensure that the person they are detaining is not armed or has no other a thing that could endanger life or health, or remove such a thing will take the removed item or weapon to the nearest police corps together with the detained person,

e. instruct any person not to enter the designated places for the necessary time or to them, provided that effective safeguarding of the general tasks is required police or municipalities,

f. stopping vehicles if the driver of the vehicle has committed an offense against safety and smoothly road traffic by failing to comply with the ban on road traffic by road signs or transport equipment. 
The weapon is a firearm, stabbing, cutting, cutting weapon and weapon of mass efficiency. The weapon also means everything that makes the attack against the body stronger. (Law,2019)

Furthermore, it is entitled to:

- require proof of identity from the person caught when the offense was committed, or from the person from whom an explanation is sought, or from the person being sought,

- request clarification from a person who can contribute to clarifying the facts relevant to the detection of the offense and the finding of his offender,

- open an apartment if there is a reasonable concern that life is at risk or that the health of the person is seriously threatened, or if there is a risk of serious damage to property and risk of delay, to enter into it and take the necessary measures to avoid the threat of danger,

- to withdraw a case that may reasonably be presumed to be forfeited in an infringement proceeding, or may be confiscated, or may be related to a criminal offense or if it is a matter of interest. A thing whose value is in a noticeable disproportion to the nature of the offense cannot be removed,

- before using coercive means, a municipal police officer is obliged to invite a person against whom he/she intervenes to refrain from doing so, with a warning that any coercive means will be used. It can only abandon the call and warning if the life or health of another person is attacked or threatened and the matter is not delayed or is prevented by other circumstances. (Law,2019)

A member of the municipal police proves his / her affiliation to a municipal police uniform with a prominently affixed identification number, a municipal police officer's card, and a "general police" verbal statement.

In connection with the performance of tasks under the Act, the Ministry keeps records of:

a. municipalities having municipal police and municipalities which have abolished the municipal police,

b. requests by municipalities for training and examination,

c. members of the municipal police who have been certified, d. data contained in municipal police activity reports. (Law,2019)

The municipality is liable for damage caused to members of the municipal police in connection with the fulfillment of the tasks set out in the Municipal Police Act. The municipality is liable for damage to the person who has provided assistance to the municipal police or its officers at their request or with their knowledge. The municipality is also liable for damage to things incurred by the victim in connection with the provision of the case. (Law,2019)

The municipality, which has established general police, is obliged by 31 March of each year to send to the Ministry a report on the activities of the municipal police for the previous calendar year. The municipal police may sign a report on the activities of the municipal police. Pursuant to the Municipal Police Act, the Ministry keeps records of municipal police. Until 31 March 2005, municipalities that have established general police have been obliged to submit to the Ministry for the first time a report on the activities of the municipal police for 2004. With a view to a uniform procedure for the handling of the report, in January 2005 the Supervisory Department sent methodological guidance to all the general police.

Municipal and municipal cops in the majority of the service are moving in the streets. It follows that many offenses are captured immediately in the bud.

\subsection{Cooperation of the municipal police with other authorities}

The general police work most closely with the police departments, most often with the relevant police departments, as well as the police and judicial police and criminal police offices. Cooperation of municipal police with the Police Force is in many cases carried out on the basis of concluded contracts between the general police and the district police department. The most common form of cooperation is the performance of joint patrol services in the provision of public order, detection of crime and the implementation of preventive activities. In the framework of preventive and security actions, members of the general police cooperate in ensuring public order in cultural, sporting and other important social events of municipalities. The general police, in 
cooperation with the police departments of the district, has significant participation in control actions aimed at serving alcohol to juveniles in restaurants and pubs. In collaboration with the District Police Inspectorates of the District Directorates of the District Police, members of the general police participate in transport-security actions. (Law,2019)

Municipal police, which is established in towns or villages in border areas, also cooperate with the border control departments of the Police Force, eg. in identifying foreign nationals. Members of the municipal police within the framework of cooperation with the Police Force provide assistance in the procedural acts of law enforcement authorities as non-participating persons and, when detecting the commission of a crime, provide the crime scene until the arrival of the Police Force patrol.

\section{ANALYSIS OF GENERAL POLICE DEVELOPMENT}

In the course of 2018, the number of established municipal police has changed. One municipal council decided to abolish the municipal police and some municipalities decided to establish municipal police. As of 31 December 2018, there were a total of 167 general police in the Slovak Republic. (Fig. 1)

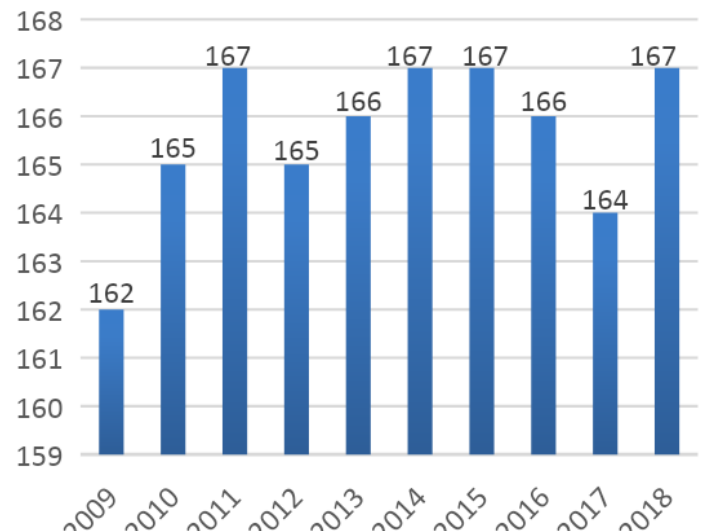

Fig. 1 Number of general police in the SR in the period 2009 - 2018 [1] (by author, 2019)

The development of the number of municipal police for the period 2009 to 2018 shows that, following increasing tendencies in the previous decade, since 2009 the number of general police has stabilized and oscillates around 167 general police. In 2018, a total of 2528 municipal police officers were registered in the Slovak Republic (Fig. 2). Most of the municipal police employed the capital of the Slovak Republic Bratislava (254), the city of Kosice (238), the city of Zilina (80) and the city of Presov (77). (Crime prevention strategy, 2018)

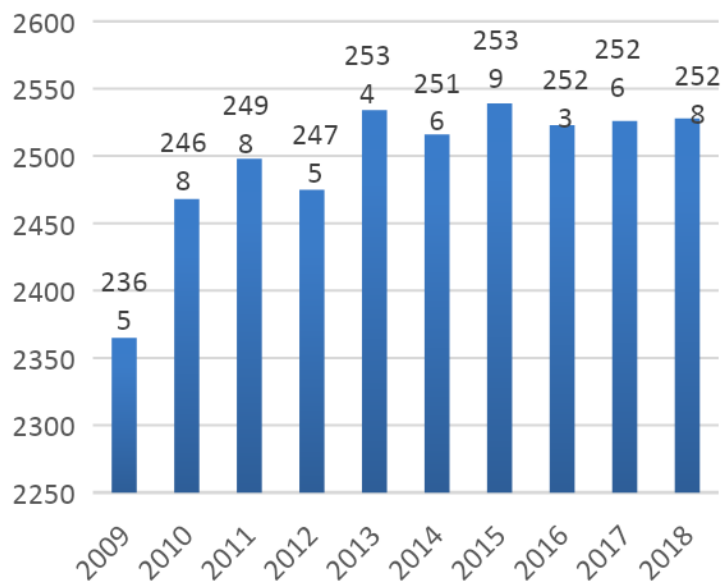

Fig. 2 Number of municipal police officers in the SR for the period 2009 - 2018 (by author, 2019)

From the point of view of the number of members of the general police employed by individual municipal police, it has been shown that general police with a lower number of members continue to dominate significantly. In 2018, almost twothirds $(61.45 \%)$ of the general police with a maximum of 10 members worked in the Slovak Republic. Of this number, there were ten general police, which employed only one municipal police officer and four general police who had no members of the municipal police. (Crime prevention strategy, 2018)

\section{AFFECTING GENERAL POLICIES ON THE SEPARATION SECTION}

One of the most important social tasks fulfilled by the general police in the Slovak Republic is the resolution of offenses. It is the part of an anti-social activity that is characterized by lower social importance. The legislature has empowered the general police to clarify the offenses that they are entitled to negotiate in the block procedure. This is a relatively wide area of this unlawful conduct, covering the offenses listed in the Act of the Slovak National Council no. 372/1990 Coll. on offenses, as amended (hereinafter referred to as "the Act on Offenses"), in the Act on Municipal Police and other regulations. The offenses that the general police can hear are as follows: 
a. traffic and road traffic offenses committed by failure to comply with the traffic sign instruction: prohibition of stopping, standing, entering, turning and turning, commanded direction of travel and bypass, reserved parking, residential, pedestrian and school zone, traffic restriction zone and traffic brand parking lot (under the municipal police law),

b. traffic and road traffic offenses committed by non-compliance with an instruction resulting from the general traffic regulation prohibiting the stopping, standing and entering of vehicles (pursuant to the Municipal Police Act),

c. offenses against public order (under the Law on Offenses),

d. offenses against civil coexistence (under the Act on Offenses), e. offenses against property (under the Law on Offenses),

f. offenses against the order in the administration by the municipality (under the Act on Offenses),

g. violations of violations of generally binding regulations of the municipality (according to the Act on Offenses),

h. offenses under Section 7 of Act no. Amending Act No. 282/2002 Coll., Regulating certain conditions for holding dogs, as amended,

i. offenses under Section 11 of Act no. 377/2004 Coll. on the protection of non-smokers and on amendments to certain acts as amended. (Report on the Activities, 2018)

The graph below shows the number of offenses registered by the general police in 2018 compared to 2017.

Table 1 Overview of detected and reported violations for 2018 and 2017 (by author, 2019)

\begin{tabular}{|l|c|c|c|c|c|c|}
\hline & $\S 22$ & $\S 47-48$ & $\S 49$ & $\S 50$ & Regulations & Others \\
\hline Year 2017 & 237380 & 22718 & 2186 & 3203 & 45010 & 9894 \\
\hline Year 2018 & 241568 & 22658 & 1870 & 3004 & 43212 & 10671 \\
\hline Difference & 4188 & -60 & -316 & -199 & -1798 & 777 \\
\hline
\end{tabular}

In 2018, the general police dealt with a total of 322,983 misdemeanors, an increase,e of 2,592 misdemeanors compared to $2016 \quad(320,391$ misdemeanors). Of this number, 261,261 offenses were detected and 61,722 offenses were reported. It is clear from the graph above that offenses against road safety and traffic flow are the dominant area of offenses targeted by the general police. From the point of view of the percentage distribution of offenses against road safety and traffic fluctuations, they represent up to $74.79 \%$ of the total number of registered offenses of municipal police in 2018. The stated proportion of offenses against road traffic safety and fluency does not reflect the real share as well as the number of offenses included in the group of "violations of generally binding regulations" (hereinafter referred to as "Regulations"), municipalities are classified as belonging to the subject area, such as parking on greenery and so on. The proportion of offenses against regulations of the municipality amounts to $13.38 \%$ of all detected and reported offenses, which were addressed by the general police in 2018. On the other hand, the smallest share was formed by offenses against civil coexistence under Section
49 of the Act on Offenses, which reached approximately $1 / 2 \%$ of all registered offenses, as well as offenses against property under Section 50 of the Offenses Act, which constitute almost $1 \%$. (Report on the Activities, 2018)

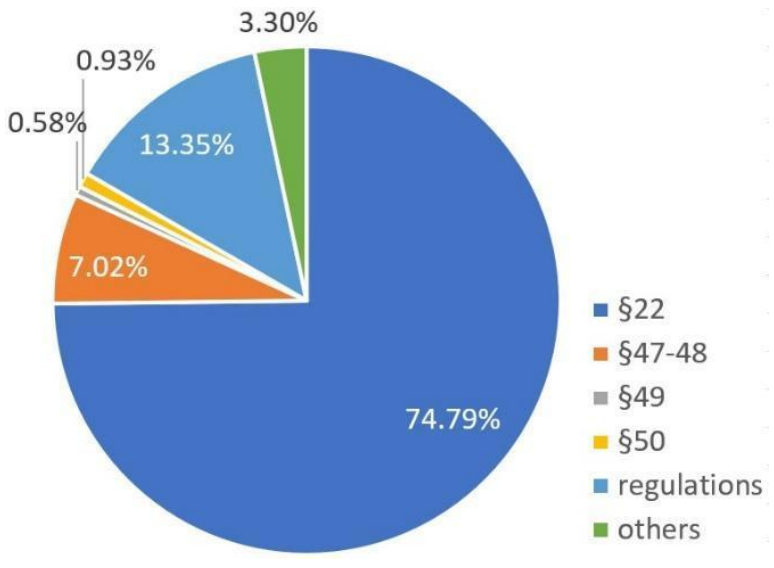

Fig. 3 Share of individual groups of registered offenses in 2018 (by author, 2019)

The trends of the various groups of offenses identified or reported to the general police in 2018 are presented in the following section of this report. 
An analysis of the activities of municipal police in the area of detecting, clarifying and dealing with offenses in block proceedings shows that the priority, in particular, for larger municipal police, is to deal with infringements of road safety and traffic. This is also confirmed by the statistical offenses detected by the general police in their own activities. In this group, the proportion of (detected) offenses against road safety and a traffic flow from all (detected) offenses were even higher, namely $75.76 \%$. (Crime prevention strategy, 2018)

Cooperation of general police with the Police Force and other entities. The cooperation of general police with other entities is carried out both for the purpose of carrying out preventive activities and in the framework of repressive activities. The municipal police most often cooperate with public authorities whose activities are developed within their territorial scope. Most often they work with the following institutions:

a. regional veterinary reports (veterinarians or clinics) - cooperation in capturing stray and stray animals, killing animals,

b. water management reports - monitoring, control and reporting of watercourses,

c. health care facilities - assistance to patrols of medical assistance; the transport of aggressive patients or persons under the influence of alcohol,

d. Slovak Fisheries Association - inspections focused on compliance with permitted catching of fish,

e. forest management - controls aimed at illegal logging,

f. Fire and rescue service and voluntary fire brigades - co-operation in reporting and disposing of fires, opening an apartment in case of fire,

g. district and regional courts - delivery of letterpost items,

h. bailiffs and notaries - delivery of letter-post items,

i. district offices - in particular the membership of representatives of municipal police in the Regional Crime Prevention Commissions and other anti-social activities. (Crime prevention strategy, 2018)

Within the framework of the resolution of the offenses, cooperation between the general police is carried out with each other. In particular, this is done to clarify offenses in cases where the offender is resident in a city other than that of the municipal police. The forms of cooperation were also extended by an amendment to the Act on the Municipal Police of 2011, which provided for the possibility of cooperation between a municipality that has established general police and a municipality that does not have general police. This cooperation of municipalities can be realized only on the basis of prior consent of municipal councils and conclusion of a written contract containing obligatory requirements according to the law on municipal police. (Report on the Activities, 2019)

In addition to the above-mentioned entities, general police cooperate with local police corps. Most of the municipal police perceive and evaluate the cooperation with the police departments highly positively. The most common areas of cooperation with the Police Force are:

a. the provision of public order, controls in hospitality establishments in the evening and at night in connection with the protection of minors and adolescents from the administration of alcoholic beverages and other addictive substances:

b. examination of notifications,

c. the provision of road accidents, transport preventive and security actions,

d. the development of reputation reports,

e. searching for wanted persons, things and motor vehicles,

f. providing records of urban camera systems in order to verify suspected offense or offense. (Report on the Activities, 2018)

\section{CONCLUSIONS}

Due to the objective assessment of the activities of the municipal police on the basis of the statistical indicators monitored, comparisons of total statistical data for the years 2009 to 2018 were prepared (statistical data from 2019 not yet available). Statistical comparisons create a realistic picture of the developmental trend in general police activities. Based on the comparison of the years 2009 to 2018 in the area of offenses under the monitored offenses, it is possible to state an overall decreasing tendency, in addition to offenses against safety and traffic flow. 
The direction of the municipal police shows the relevant statistical indicators, despite the fact that the basic tasks of the municipal police include in particular the protection of public order in the municipality. The activities of these municipal departments continue to focus largely on one narrow area of illegal behavior, namely offenses against road safety and traffic.

It can be stated that the activity and focus of individual municipal police depend on the security situation of the region as well as on the priorities determined by the municipal authorities established by the municipal police.

The municipal police, as an optional body of the municipal council, provides primary and fundamental support for general public order matters. By consistently applying the statutory standards by which municipal police officers operate in the exercise of their profession, they ensure public order in the founding competence of the city. A distinctive element of situational prevention is a modern and constantly supplementing camera system of the city or municipality, which is used to detect "street crime", perpetrators of offenses, crimes, traffic accidents and the overall movement of citizens and visitors to the city and the municipality. In addition to the above, camera systems use law enforcement agencies to provide the required information (camera system records) under the Personal Data Protection Act. Material values in the possession of the city and individuals protect the city police by operating the central protection desk, but the most fundamental element of public order protection is the consistent execution of the patrol service of uniformed members of the municipal police. For this reason, it is also necessary to complement the number of citizens corresponding to the population of the city and the geographical breakdown, which is, however, a long-standing fundamental issue in view of the overall social situation, the labor market situation and the attractiveness of the profession. Municipal police have performed the tasks of urban police in securing general public order, life, health and property protection and environmental protection in the city through individual districts and education and police departments.

\section{WORKS CITED}

Law no. 564/1991 codex, Law of the Slovak National Council on the Municipal Police (2019, minv.sk) https://www.minv.sk/?pravne_predpisy.

Report on the Activities of Municipal Police in the Slovak Republic for 2018 - Internal Documents of the Ministry of Interior of the Slovak Republic. Available at: https://infoweb.minv.sk/.

Report on the fulfillment of tasks resulting from the Crime Prevention Strategy and Other Anti-Social Activities in the Slovak Republic for the Years 2016 - 2020 Completed by the Ministry of Interior of the Slovak Republic in 2018 - Internal Documents of the Ministry of Interior of the Slovak Republic. Available at: https: // infoweb.minv.sk/.

Soltes, V. (2017). Vplyv ekonomickeho vyvoja regiónu na bezpecnost' obcanov: dizertacna praca. Zilinska univerzita, Fakulta bezpecnostneho inzinierstva. pp. 126.

Strategy of crime prevention and other anti-social activities in the Slovak Republic for 2016 - 2020 Available at: https: // infoweb.minv.sk/.

Velas, A. (2014, 10 28). Vzdelavanie v oblasti komercnej bezpecnosti v Slovenskej republike. Security and crisis management in real environment: mezinarodni konference: sborník prednasek. Praha: European Institute of security and crisis management, ISBN 978-80-88048-00-8. pp. 715-721.

Velas, A. (2017). Bezpecnost' v lokalnom prostredí. Zborník vedeckych prac z medzinarodneho workshopu SECULIN 2017: [11.-13.10.2017], Zuberec. Zilina : EDIS-Vydavatel'ske centrum ZU. pp. 204. ISBN 978-80-554-1398-3.

Vel'as, A., Boros, M., \& Losonczi, P. (2018). Testovanie detekcnej schopnosti vybranych komponentov poplachovych systemov. Zilina: Zilinska univerzita, pp.133. ISBN 978-80-554-1453-9. 


\section{Acknowledgment}

The article is supported by the project VEGA 1/0628/18 Minimizing the degree of subjective estimates of experts in security practice using quantitative and qualitative methods.

Received for publishing: $\quad$ 09.06.2019

Revision received: $\quad$ 28.06.2019

Accepted for publication: $\quad 10.07 .2019$

\section{How to cite this article?}

Style - APA Sixth Edition:

Molovcakova, N. (2019, July 15). Overview of the Most Exceptional Fields of Municipal Polices in the Slovak Republic. (Z. Cekerevac, Ed.) MEST Journal, 7(2), 94-102. doi:10.12709/mest.07.07.02.12

Style - Chicago Sixteenth Edition:

Molovcakova, Nina. 2019. "Overview of the Most Exceptional Fields of Municipal Polices in the Slovak Republic." Edited by Zoran Cekerevac. MEST Journal (MESTE) 7 (2): 94-102. doi:10.12709/mest.07.07.02.12.

Style - GOST Name Sort:

Molovcakova Nina Overview of the Most Exceptional Fields of Municipal Polices in the Slovak Republic [Journal] // MEST Journal / ed. Cekerevac Zoran. - Belgrade - Toronto : MESTE, July 15, 2019. - 2 : Vol. 7. - pp. 94-102.

Style - Harvard Anglia:

Molovcakova, N., 2019. Overview of the Most Exceptional Fields of Municipal Polices in the Slovak Republic. MEST Journal, 15 July, 7(2), pp. 94-102.

Style - ISO 690 Numerical Reference:

Overview of the Most Exceptional Fields of Municipal Polices in the Slovak Republic. Molovcakova, Nina. [ed.] Zoran Cekerevac. 2, Belgrade - Toronto : MESTE, July 15, 2019, MEST Journal, Vol. 7, pp. 94-102. 